\title{
Study on the Biotribological Properties of Ti6Al7Nb and Ultra High Density Molecular Weight Polyethylene at Different Lubricant Temperature
}

\author{
Songquan WANG ${ }^{1}$, Ningning $\mathrm{HU}^{1 *}$, Dahan $\mathrm{LI}^{1}$, Deqi SUN ${ }^{1}$, Dekun $\mathrm{ZHANG}^{2}$ \\ ${ }^{1}$ School of Mechatronic Engineering, JiangSu Normal University, 101\# Shanghai Road, Xuzhou 221116, China \\ ${ }^{2}$ School of Materials Science and Engineering, China University of Mining and Technology, l\# University Road, Xuzhou \\ 221116, China \\ crossref http://dx.doi.org/10.5755/j02.ms.22794
}

Received 18 February 2019; accepted 26 April 2019

\begin{abstract}
Higher frictional heat will be produced during the service process of artificial hip joint prosthesis in vivo than natural joint, which would cause the rise of the temperature of synovial fluid and the change of the wear resistance of prosthetic materials. In this work, the biotribological properties of $\mathrm{ZrO}_{2} / \mathrm{Ti} 6 \mathrm{Al} 7 \mathrm{Nb}$ and $\mathrm{ZrO}_{2} / \mathrm{UHMWPE}$ pairs at different lubricant temperatures were investigated. The results show that there is a strong correlation between the wettability and average friction coefficient of Ti6Al7Nb, while there is also a strong correlation between the wettability and mass loss of UHMWPE. The wear loss of Ti6Al7Nb and UHMWPE decreases gradually and the friction coefficient increases gradually as the lubricant temperature rises from $20{ }^{\circ} \mathrm{C}$ to $46^{\circ} \mathrm{C}$, which is mainly affected by the precipitation process of protein. As a protective layer, it can reduce the wear rate, but as a third body, it can participate in the friction process and increase the friction coefficient. The characteristics of lubricant change greatly at $60^{\circ} \mathrm{C}$, but the increase of temperature is not the only reason for the precipitation of synovial protein. The synergistic effect with the friction process results in a significant change on the wear mechanism of Ti6Al7Nb and UHMWPE under this condition. The wear mechanism of Ti6Al7Nb is mainly abrasive wear and adhesion wear at different lubricant temperature. With the increase of lubricant temperature, the proportion of adhesion wear mechanism becomes larger. Due to the low thermal deformation temperature and thermal conductivity, the wear mechanism of UHMWPE changed obviously at $60^{\circ} \mathrm{C}$, and the wear morphology is mainly plastic deformation.
\end{abstract}

Keywords: lubricant temperature, biotribological properties, Ti6Al7Nb, UHMWPE, wear mechanism.

\section{INTRODUCTION}

Evaluating the service life of artificial joint and analyzing its failure mechanism has been a research hotspot in the field of bioengineering [1,2]. Taking the hip prosthesis as an example, it takes about 100-300 million cycles of body weight load each year in the body. And its service life is generally required to reach $10-20$ years. Some study found that the looseness caused by friction and wear in vivo was the most important form of failure [3, 4]. While in the study of the failure process of hip prosthesis, an important factor was often overlooked. During the operation of the hip prosthesis in the body, the joint interface (including the ball-ball friction interface, the joint assembly link interface, etc.) will inevitably generate frictional heat due to the friction effect, resulting in the increase of local temperature of the prosthesis [5-8]. It has been shown that the artificial hip prosthesis possesses higher frictional heat than natural joints. The temperature of the prosthesis head can reach $43{ }^{\circ} \mathrm{C}$ under certain exercise mode [9]. However, the increasing of patient's weight and the more severe exercise can further increase the femoral head temperature. Pritchett conducted a study on the frictional heat of nine different femoral head/acetabular combinations in vivo. The results showed that the hip prosthesis would generate more heat than the natural hip joint, and the frictional heat could not dissipate quickly, which might aggravate the frictional wear of the prosthesis interface [10]. In addition, the temperature of the synovial fluid and surrounding tissues increases due to the heat convection and heat conduction [11]. Finite element analysis found that artificial hip friction process can make the temperature of surrounding synovial fluid exceed $46^{\circ} \mathrm{C}$ [12]. And whether the temperature rise of the lubricant will influence the service life of the prosthesis is our most concern.

As we all know, Ultra High Density Molecular Weight Polyethilene (UHMWPE) has always been used as an alternative material for acetabular cup in total hip replacement $[13,14]$. In addition, titanium and titanium alloys have the characteristics of low relative density, high elastic modulus, high mechanical strength, good biocompatibility, superior corrosion resistance and fatigue resistance, which have become the first choice for surgical implants. Among them, Ti6Al4V alloy is the most widely used [15]. However, some studies have found that metal element $\mathrm{V}$ has certain sensitization to human cells. At present, it tends to use non-toxic $\mathrm{Nb}$ element instead of $\mathrm{V}$ element. Similar to Ti6AL4V alloy, Ti6Al7Nb alloy also has good wear resistance, corrosion resistance and biocompatibility [16]. Therefore, Ti6Al7Nb alloy is increasingly widely used in the application of joint prosthesis materials $[17,18]$. In order to study the effect of the lubricant temperature on the wear resistance of Ti6Al7Nb alloy and UHMWPE, a friction test was carried

\footnotetext{
* Corresponding author. Tel.: +8618205201700; fax: +86-516-83500252.

E-mail address: huning_ning@163.com (N. Hu)
} 
out with the $\mathrm{ZrO}_{2}$ ceramic ball/Ti6Al7Nb alloy disk and $\mathrm{ZrO}_{2}$ ceramic ball/UHMWPE disk as friction pairs, and the $25 \%$ NBS solutions (25\% volume of Newborn Bovine Serum) with different temperature as lubricating medium in this paper. The effect of the lubricant temperature on the wear resistance of prosthesis materials was discussed based on the analysis of the lubrication characteristics of lubricant, the friction behavior and wear mechanism of Ti6Al7Nb alloy and UHMWPE.

\section{EXPERIMENTAL DETAILS}

\subsection{Experimental materials}

In this paper, the wear mode of friction pair was selected as ball-disk reciprocating sliding. $\mathrm{ZrO}_{2}$ ceramic ball was acquired as upper sample from Shanghai Gongtao Ceramics Co., Ltd (Shanghai, China). The diameter of the ceramic ball is $10 \mathrm{~mm}$, and the roughness is less than $0.01 \mu \mathrm{m}$ by surface finishing process. Ti6Al7 Nb alloy and UHMWPE were acquired as lower sample from Luoyang Sunrui Titanium Precision Casting Co., Ltd (Luoyang, China) and Kuajun Plastic Trade Co., Ltd (Shanghai, China) respectively. The lower samples were processed into a disk of $\Phi 25 \mathrm{~mm} \times 3 \mathrm{~mm}$. The chemical composition of Ti6Al7Nb is shown in Table 1.

Table 1. Chemical composition of Ti6Al7Nb alloy

\begin{tabular}{|c|c|c|c|c|c|c|c|c|c|c|}
\hline $\begin{array}{c}\text { Element } \\
\text { wt.\% }\end{array}$ & $\mathrm{Al}$ & $\mathrm{Nb}$ & $\mathrm{Ta}$ & $\mathrm{Fe}$ & $\mathrm{Mo}$ & $\mathrm{C}$ & $\mathrm{N}$ & $\mathrm{O}$ & $\mathrm{H}$ & $\mathrm{Ti}$ \\
\cline { 2 - 9 } & 6.0 & 6.97 & 0.36 & 0.22 & 0.005 & 0.10 & 0.07 & 0.20 & 0.02 & $\mathrm{Bal}$ \\
\hline
\end{tabular}

The polished samples were cleaned by ultrasonic wave (SK1200H) in the alcohol solution and put into the drying box (DHG-9030A) for 24 hours. The dried samples were weighed using an electronic balance (Sartorius BP211D) with a resolution of $0.01 \mathrm{mg}$. Each sample was weighed 5 times and averaged after removing the maximum and minimum values. NBS solution was acquired as lubricant from Hangzhou Si Ji Qing Co., Ltd (Hangzhou, China). Before the friction test, NBS solution was diluted to $25 \%$ (volume fraction) by the ultra-pure water and frozen for preservation.

\subsection{Testing of lubricant properties}

The BCA method was used to measure the mean protein concentration of NBS solutions at different temperatures. Before the test, $2 \mathrm{ml}$ of NBS solution (25\% volume fraction) was respectively placed in 6 constant temperature environments for $24 \mathrm{~h}$. Each group had 3 parallel specimens. In the control group, NBS solution (25\% volume fraction) was added directly. The multifunctional enzyme labelling instrument (Synergy 2 SLFPA) was used to detect the absorbance value at $570 \mathrm{~nm}$ wavelength (OD570). The protein concentration was determined strictly according to the method of BCA kit (Beyotime Biological Reagent Company, China). The contact angles of NBS solution at different temperatures on Ti6Al7Nb and UHMWPE were measured by water drop method using contact angle measuring instrument (JC2000D2A). The temperatures of NBS solution were controlled by water bath heating and ice cooling, respectively. The mean value of three stable test results (equilibrium contact angle) was taken as the intrinsic contact angle of the lubricant on the solid surface.

\subsection{Friction test at constant temperature}

The friction test was carried out by using RTEC multifunctional friction and wear testing machine (RTECInstrument INC., USA). The schematic diagram of the test device, partial physical diagram of the test machine and the samples are shown in Fig. 1. The lower sample was fixed in the test tank which was reciprocated to realize the reciprocating sliding friction. During the friction test, the constant temperature of the lubricant in the test tank is realized by the speed control of the adjustable peristaltic pump (KCP3-X), which was connected to a beaker containing NBS solution ( $25 \%$ volume fraction) at different temperatures in an thermostat water bath (HH-1).

Table 2 shows the experimental parameters of the friction test. Three sets of parallel tests were conducted under each condition. The environment temperature of all friction tests were controlled at $25^{\circ} \mathrm{C}$. Before the experiment, isothermal NBS solution was added to the test tank and the beaker respectively. The lubrication in the test tank and the beaker were circulated by the peristaltic pump.

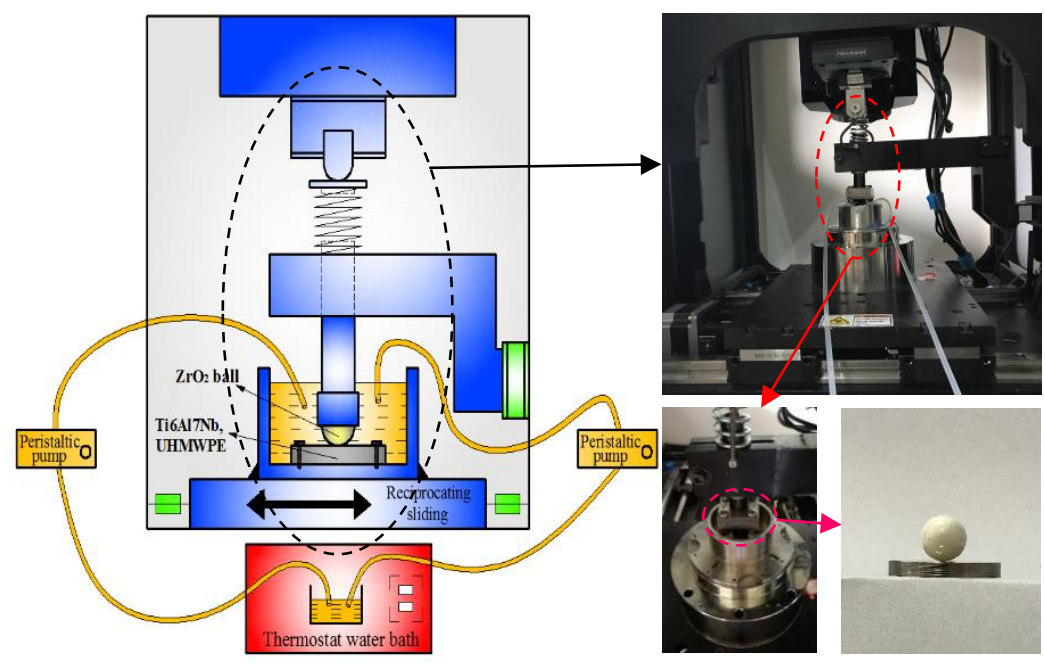

Fig. 1. Schematic diagram of the test device, partial physical diagram of the test machine 
The thermometer (Flank-88554) was used to measure the lubricant temperature in the test tank. The lubricant temperatures of $37{ }^{\circ} \mathrm{C}, 46^{\circ} \mathrm{C}$ and $60{ }^{\circ} \mathrm{C}$ were obtained by the heating function of the thermostat water bath, while the lubricant temperatures of $10{ }^{\circ} \mathrm{C}$ and $20^{\circ} \mathrm{C}$ were obtained by adding frozen liquid to the thermostat water bath. The error of the stable lubricant temperature in the test tank can be controlled in the range of $\pm 0.5^{\circ} \mathrm{C}$ by adjusting the speed of the peristaltic pump.

The Ti6Al7Nb and UHMWPE samples were ultrasonically washed with the applied surface current of 2 A after friction tests, and then dried and weighed to calculate the wear mass. Similarly, each sample was weighed 5 times and averaged after removing the maximum and minimum values. The final wear mass was the average of three parallel trials. The friction coefficients under different conditions were read by the RTEC data collection system and made into a curve by the Origin software. In addition, in order to analyze the wear mechanism of Ti6Al7Nb alloy and UHMWPE, the worn surface of the samples were examined using a scanning electron microscopy (SEM, S-3000, Hitachi Limited INC., Japan).

Table 2. Experimental parameters for friction testing

\begin{tabular}{|l|l|}
\hline Experimental condition & Parameter \\
\hline Upper sample & $\mathrm{ZrO}_{2}$ \\
\hline Lower sample & $\mathrm{Ti6Al7Nb}$, UHMWPE \\
\hline Load/N & 100 \\
\hline Sliding speed/mm/s & 10 \\
\hline Sliding distance $/ \mathrm{mm}$ & 5 \\
\hline Lubrication condition & $25 \%$ NBS solution \\
\hline Temperature of synovial fluid, ${ }^{\circ} \mathrm{C}$ & $10,20,37,46,60$ \\
\hline Experimental time, $\mathrm{h}$ & 1 \\
\hline
\end{tabular}

\section{RESULTS AND DISCUSSION}

\subsection{Analysis of lubrication characteristics}

Table 3 shows the protein concentration of $25 \%$ NBS solution under different conditions. The protein concentration of $25 \%$ NBS solution in the control group is about $27 \mathrm{mg} / \mathrm{ml}$, which decreases significantly after $24 \mathrm{~h}$ storage at different temperatures. Although there are exceptions under some conditions, the protein concentration tends to decrease with the increase of temperature. The protein concentration is the highest (about $13.14286 \mathrm{mg} / \mathrm{ml}$ ) at $4{ }^{\circ} \mathrm{C}$, and decreases to $11.83664 \mathrm{mg} / \mathrm{ml}$ at $60{ }^{\circ} \mathrm{C}$. The average value of protein concentration after $24 \mathrm{~h}$ storage at the six different temperatures $\left(4{ }^{\circ} \mathrm{C}, 10{ }^{\circ} \mathrm{C}, 20{ }^{\circ} \mathrm{C}, 37^{\circ} \mathrm{C}\right.$, $46^{\circ} \mathrm{C}$ and $60{ }^{\circ} \mathrm{C}$ ) was $12.23529 \mathrm{mg} / \mathrm{ml}$, which was about $15 \mathrm{mg} / \mathrm{ml}$ lower than the protein concentration of the control group. Although it has been reported that protein precipitation will occur in synovial fluid with the increase of temperature $[9,19]$, this change in quantity is not particularly evident according to our experimental results. According to Liao's results [20, 21], protein precipitation in bovine serum will increase significantly when the lubricant temperature exceeded $60{ }^{\circ} \mathrm{C}$. However, according to the result of Table 3, although the average protein concentration tends to decrease with the increase of temperature, the average protein concentration doesn't decrease significantly when the lubricant temperature is $60^{\circ} \mathrm{C}$. As Liao's conclusion is obtained during the friction test, we believe that the formation of a large number of protein precipitates is caused by the frictional heat generated by friction, which causes the lubricant temperature to rise further. Because the instantaneous maximum temperature of lubricant can't be captured, the temperature that causes rapid increase of protein precipitation may be higher than $60^{\circ} \mathrm{C}$. In addition, other factors in the friction process may also lead to protein precipitation, such as the shearing of lubricant between the ball and disk.

Fig. 2 shows the contact angles at the $25 \%$ NBS solution-UHMWPE interface and the $25 \%$ NBS solutionTi6Al7 Nb interface at different temperature.

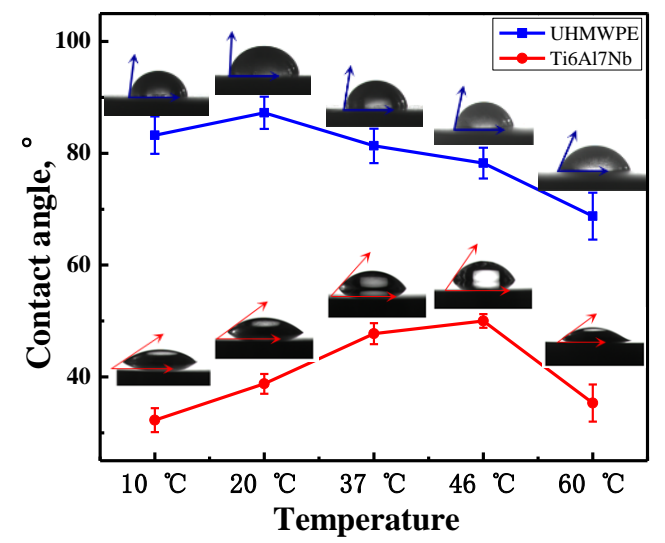

Fig. 2. Contact angles at the $25 \%$ NBS solution-UHMWPE interface and the $25 \%$ NBS solution- Ti6Al7Nb interface at different temperature

The contact angles at the $25 \%$ NBS solutionUHMWPE interface decreases with the increase of temperature from $20{ }^{\circ} \mathrm{C}$ to $60{ }^{\circ} \mathrm{C}$. Meanwhile, the contact angles at the $25 \%$ NBS solution-Ti6Al7Nb interface increases with the increase of temperature from $10^{\circ} \mathrm{C}$ to $46{ }^{\circ} \mathrm{C}$. When the lubricant temperature is $60^{\circ} \mathrm{C}$, the contact angle at the $25 \%$ NBS solution-Ti6Al7 Nb interface sharply reduces to about $35.33^{\circ}$. In addition, the contact angle at the $25 \%$ NBS solution-Ti6Al7Nb interface is always greater than that at the $25 \%$ NBS solution-UHMWPE interface at the same temperature. Surface wettability refers to the spreadability and propensity of a liquid on a solid surface, which can be reflected directly by the solid-liquid contact angle. According to the Young's equation [22], the smaller the contact angle, the better the surface wettability, and the stronger the spreading ability of the fluid on the solid surface. The wettability of the $25 \%$ NBS solution gradually decreases with the increase of temperature from $10^{\circ} \mathrm{C}$ to $46^{\circ} \mathrm{C}$ on the surface of Ti6Al7Nb, which gradually increases with increase of temperature from $20{ }^{\circ} \mathrm{C}$ to $60{ }^{\circ} \mathrm{C}$ on the surface of UHMWPE.

Table 3. Protein concentration of $25 \%$ NBS solution under different conditions

\begin{tabular}{|c|c|c|c|c|c|c|c|}
\hline Temperature & Control group & $4{ }^{\circ} \mathrm{C}$ & $10^{\circ} \mathrm{C}$ & $20^{\circ} \mathrm{C}$ & $37^{\circ} \mathrm{C}$ & $46^{\circ} \mathrm{C}$ & $60{ }^{\circ} \mathrm{C}$ \\
\hline Protein concentration, $\mathrm{mg} / \mathrm{ml}$ & 27.3078 & 13.14286 & 12.75269 & 11.87905 & 12.37948 & 11.42102 & 11.83664 \\
\hline
\end{tabular}


Similarly, the wettability of the $25 \%$ NBS solution on the surface of $\mathrm{Ti} 6 \mathrm{Al} \mathrm{N} \mathrm{Nb}$ is always better than that on the surface of UHMWPE at the same temperature. According to the results of protein concentration of $25 \%$ NBS solution under different conditions, although the protein concentration decreases with the increase of temperature, it is not enough to cause drastic changes in wettability at $60{ }^{\circ} \mathrm{C}$. In addition to the protein concentration, there are other components in $25 \%$ NBS solution that affect wettability.

\subsection{Analysis of friction characteristics}

Fig. 3 shows the mass loss of Ti6Al7Nb and UHMWPE samples under the loading force of $100 \mathrm{~N}$ at different lubricant temperatures. The mass loss of Ti6Al7Nb sample gradually increases with the increase of lubrication temperature from $10{ }^{\circ} \mathrm{C}-20{ }^{\circ} \mathrm{C}$, which is the highest (about $0.7 \mathrm{mg}$ ) when the lubrication temperature is $20^{\circ} \mathrm{C}$.

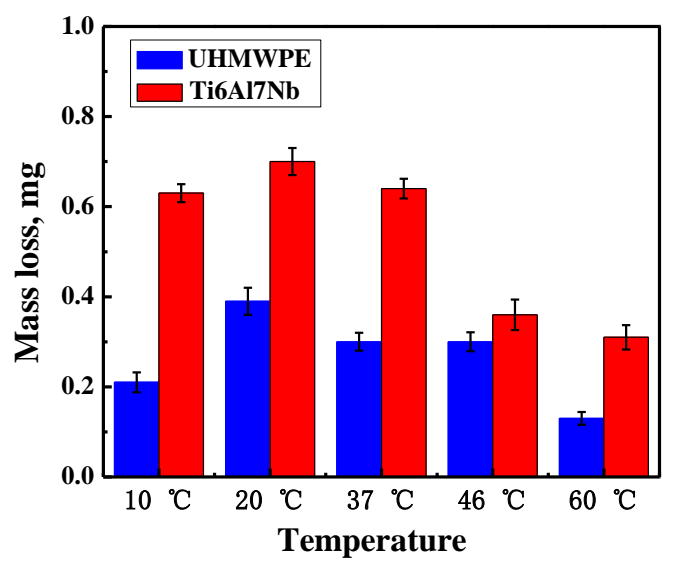

Fig. 3. Mass loss of Ti6Al7Nb and UHMWPE in lubrication with different temperature

However, when the lubrication temperature is higher than $37^{\circ} \mathrm{C}$, the mass loss of Ti6Al7Nb sample gradually decreases with the increase of lubrication temperature. When the lubrication temperature is $60{ }^{\circ} \mathrm{C}$, the mass loss of Ti6Al7Nb sample (about $0.31 \mathrm{mg}$ ) is the lowest. Generally, when the lubrication temperature is higher than $20^{\circ} \mathrm{C}$, the higher the lubrication temperature, the smaller the mass loss of Ti6Al7Nb sample, the better the wear resistance of Ti6Al7Nb sample. Especially, in the process of the lubricant temperature changing from $37^{\circ} \mathrm{C}$ to $46^{\circ} \mathrm{C}$, the wear resistance of Ti6Al7Nb sample has been greatly changed. This may be because that the protein precipitated from lubrication at high temperature is squeezed into the friction interface, which results in the change of wear mechanism of $\mathrm{ZrO}_{2} / \mathrm{Ti}_{6} \mathrm{Al}_{7} \mathrm{Nb}$ pairs. The change trend of the mass loss of UHMWPE with the increase of lubricant temperature is consistent with that of Ti6Al7 Nb, which is also consistent with the change trend of contact angle of UHMWPE with the increase of lubricant temperature. In addition, the mass loss of Ti6Al7Nb is greater than that of UHMWPE under the same condition. According to the results of Table 3 and Liao's research [20], with the increase of lubricant temperature, the precipitated protein will be attached to the worn surface as a protective layer, which can reduce the wear loss of the substrate.

Fig. $4 \mathrm{a}$ and $\mathrm{b}$ show the variation of friction coefficient of Ti6Al7Nb and UHMWPE with the extension of test time at different lubricant temperature, respectively. In Fig. 4 a, the variation of friction coefficient with the extension of test time is similar at $10{ }^{\circ} \mathrm{C}$ and $20^{\circ} \mathrm{C}$. The initial friction coefficient is not much different (about 0.3), and then it drops rapidly around $500 \mathrm{~s}$ and reaches a stable level around $700 \mathrm{~s}$. After that, the friction coefficient has been relatively stable. At $37^{\circ} \mathrm{C}, 46^{\circ} \mathrm{C}$ and $60{ }^{\circ} \mathrm{C}$, the variation of friction coefficient with the extension of test time in the first $600 \mathrm{~s}$ is consistent with which under the other two temperature. However, the friction coefficient will increase slightly with the further progress of friction when it is lowered to the lowest point, and keep a high level at the later stage of wear. At the beginning of the test, the upper and lower specimens are in line contact mode. The contact load is larger under the same normal force loading condition, which results in a larger initial friction coefficient. As the test continues, the contact mode between the upper and lower specimens gradually changes from line contact to surface contact. And the friction coefficient gradually decreases during this process. With the further extension of test time, the friction process tends to be stable because the contact mode between the upper and lower samples is no longer changed. With the increase of lubricant temperature, the precipitation of protein can be used as a protective layer to reduce the wear of the matrix material, but as a third body in the friction process, it can increase the friction coefficient to a certain extent. In Fig. 4 b, the variation of friction coefficient of UHMWPE is different from that of Ti6Al7Nb.

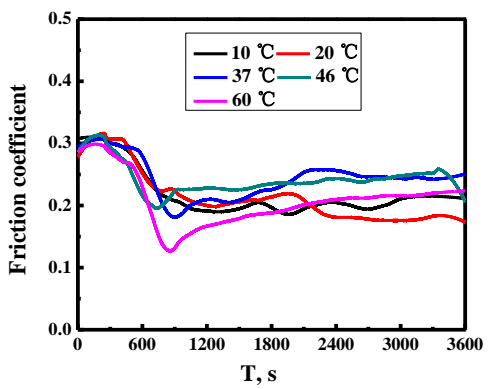

a

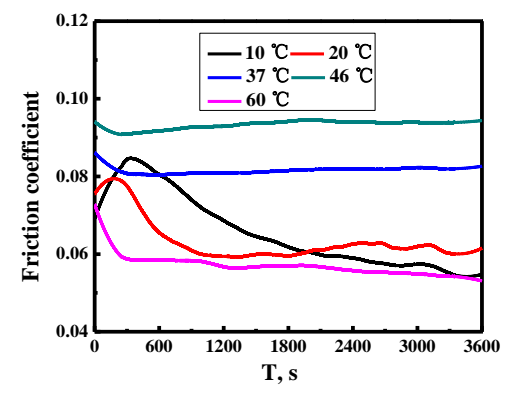

b

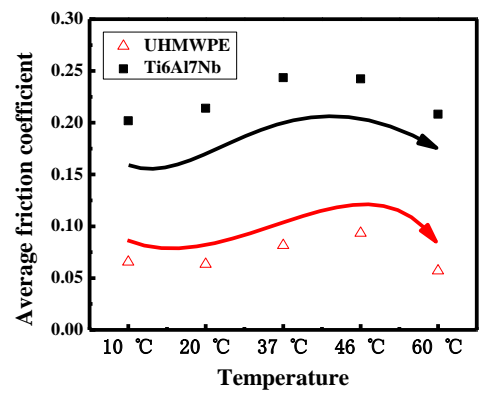

c

Fig. 4. a - variation of friction coefficient of Ti6Al7Nb; b-UHMWPE with the extension of test time at different lubricant temperature; $\mathrm{c}-$ the average friction coefficients of Ti6A17Nb and UHMWPE under different lubricant temperature 
The change curves of friction coefficient with the extension of test time are similar at $10{ }^{\circ} \mathrm{C}$ and $20^{\circ} \mathrm{C}$. Both of them increase first and then decrease to a plateau. At $37^{\circ} \mathrm{C}, 46^{\circ} \mathrm{C}$ and $60{ }^{\circ} \mathrm{C}$, the friction coefficient decrease rapidly and then become stable. Compared with Ti6Al7Nb, the hardness of UHMWPE is lower, which results in a short point contact time during the friction process. The friction of UHMWPE soon enters the stage of surface contact friction. Similar to Ti6Al7Nb, the friction coefficients of UHMWPE at $37{ }^{\circ} \mathrm{C}$ and $46^{\circ} \mathrm{C}$ are higher than those at $10^{\circ} \mathrm{C}$ and $20^{\circ} \mathrm{C}$, which again reflects the high influence of protein precipitation on the friction process and the wear mechanism. In addition, the friction coefficient of the whole friction process is always the lowest at $60^{\circ} \mathrm{C}$.

Fig. $4 \mathrm{c}$ shows the average friction coefficients of Ti6Al7Nb and UHMWPE under different lubricant temperature. The variation of the average friction coefficient of the two materials with the change of the lubricant temperature is the same. The average friction coefficient increases with the increase of lubricant temperature before $46^{\circ} \mathrm{C}$, but decreases sharply at $60{ }^{\circ} \mathrm{C}$, which indicates that the friction process has changed significantly at $60{ }^{\circ} \mathrm{C}$. The average friction coefficient of UHMWPE is lower than that of Ti6Al7Nb under the same lubricant temperature.

Referring to a large number of literatures, it is found that the relationship between the wettability of lubricants and tribological behavior of contact surfaces is not fully understood, especially in the case of biomaterials [23-26]. But it is certain that the wetting degree of lubricants has great influence on the friction and wear properties of materials. It is well known that the contact angle represents the wettability of lubricants, which can reflect the lubrication performance of the lubricants to a certain extent. However, according to the results of our experiments, the relationship between the contact angle and lubrication characteristics becomes very complex at the temperature that can change the characteristics of lubricant. When discussing the influence of wettability on the lubrication characteristics of lubricant, the physical and chemical properties of lubricant should also be considered. Combining the results of wear and friction coefficient tests, it is found that the wettability of lubricant at different temperatures on the surface of UHMWPE is well correlated with the results of mass loss of UHMWPE (as shown in
Fig. 5 a), while the wettability of lubricant at different temperatures on the surface of $\mathrm{Ti} 6 \mathrm{Al} 7 \mathrm{Nb}$ is well correlated with the results of average friction coefficient of Ti6Al7Nb (as shown in Fig. 5 b). The mass loss of UHMWPE and Ti6Al7Nb decrease gradually at $20-46{ }^{\circ} \mathrm{C}$, correspondingly, the friction coefficient increase gradually (as shown in Fig. 5 c). This is mainly due to the fact that the protein precipitation as a protective layer can weaken the matrix wear. But at the same time, the protein precipitation can also participate in the friction process as a third body abrasive particle, which can increase the friction coefficient. In addition, the contact angle of NBS solution on Ti6Al7Nb and UHMWPE increases gradually as the temperature rises from $10{ }^{\circ} \mathrm{C}$ to $20^{\circ} \mathrm{C}$, and the mass loss of the two materials also increases gradually. This indicates that the wear resistance of Ti6Al7Nb and UHMWPE during this process is mainly influenced by the wettability of NBS solution. And the protein precipitation at these two temperatures is less, which has a weak influence on the wear process.

\subsection{Analysis of wear mechanism}

The local magnification of the wear morphology of Ti6Al7Nb at different lubricant temperature is observed (Fig. 6). Firstly, the wear morphology of Ti6Al7Nb is similar at $10^{\circ} \mathrm{C}, 20^{\circ} \mathrm{C}$ and $37^{\circ} \mathrm{C}$, so only the representative surface micro-morphology at $37^{\circ} \mathrm{C}$ is shown here. It is found that the number of debris in the center of the wear scar increases with the increase of lubricant temperature from $37{ }^{\circ} \mathrm{C}$ to $46^{\circ} \mathrm{C}$. The plough grooves in the central region are shallow and few at $37^{\circ} \mathrm{C}$. The main wear morphologies are pitting and spalling, which indicates that the main wear mechanism in the central region is adhesive wear. However, the wear morphologies of upper and lower boundary are mainly plough grooves, which show that the wear mechanism of upper and lower boundary is mainly abrasive wear. The plough grooves and spalling morphologies were distributed in the wear center and upper or lower boundary at $46{ }^{\circ} \mathrm{C}$ and $60{ }^{\circ} \mathrm{C}$, which shows that the wear mechanisms under these two conditions are mainly abrasive wear and adhesion wear. In addition, the wear mechanism of the central area is consistent with that of the upper and lower boundary. The number of plough grooves on the upper and lower boundary is obviously more than that in the central area at $37^{\circ} \mathrm{C}$.

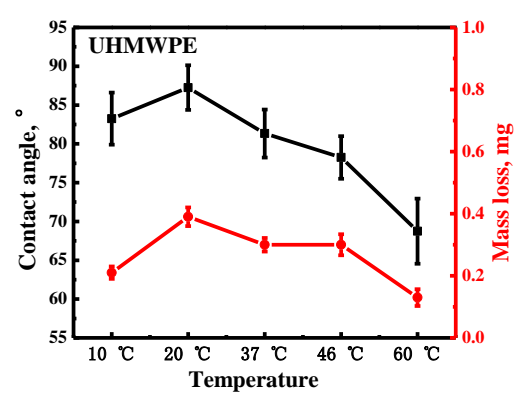

a

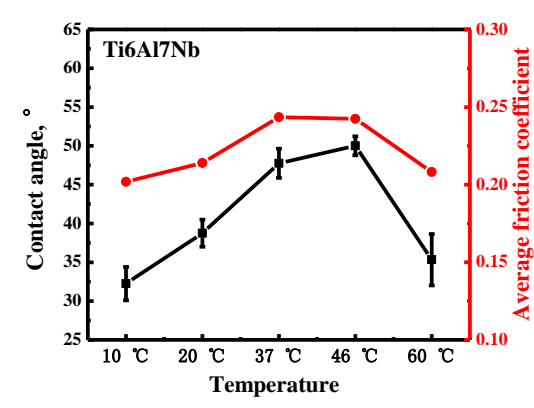

b

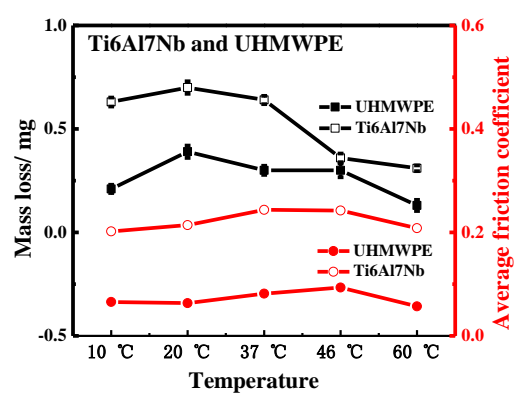

$\mathrm{c}$

Fig. 5. Mutual relationship of contact angle, average friction coefficient and mass loss of Ti6Al7Nb and UHMWPE 


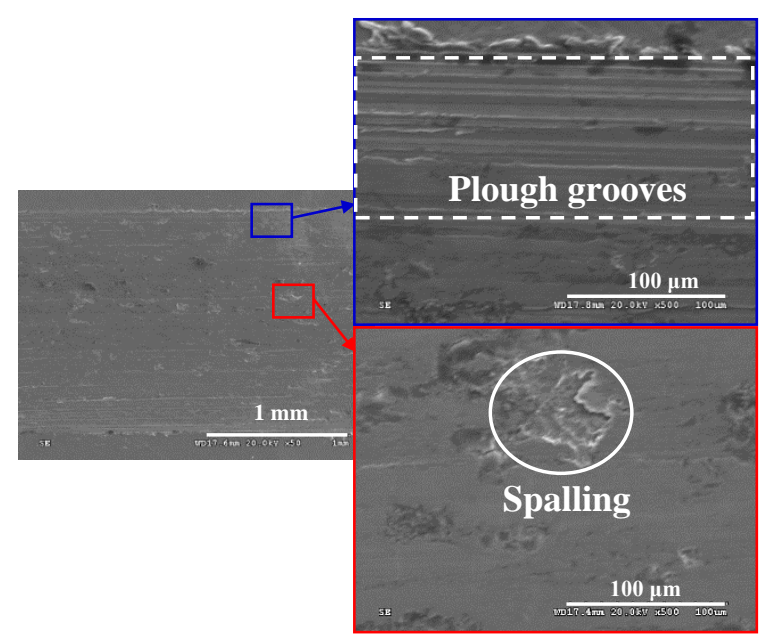

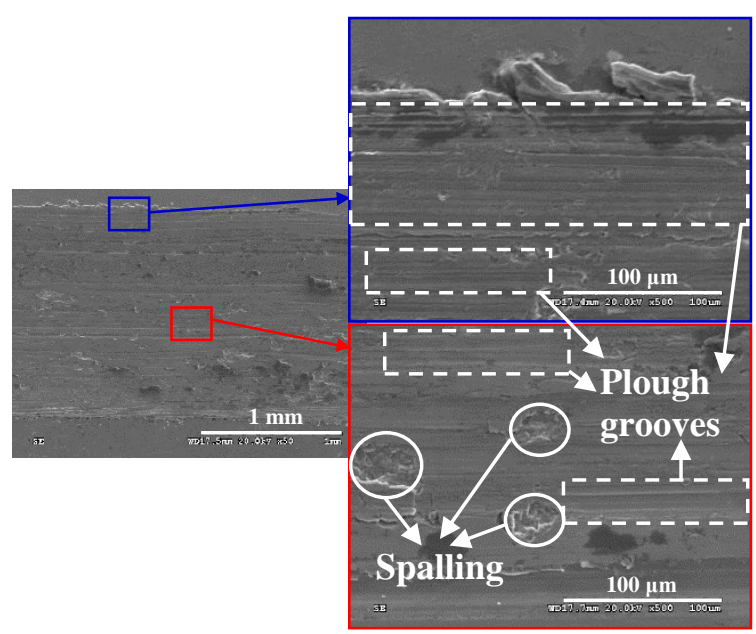

b

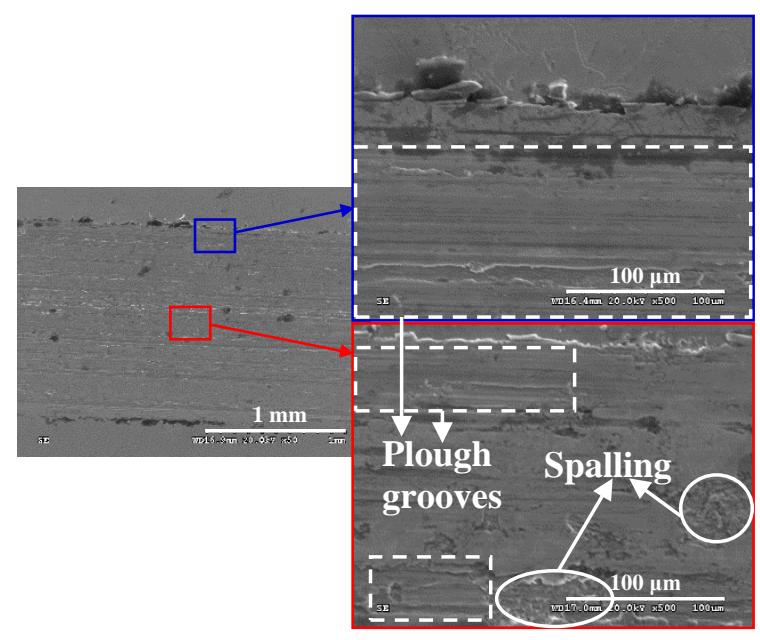

$\mathrm{c}$

Fig. 6. Local magnification of the wear morphology of Ti6Al7Nb at different lubricant temperature: $\mathrm{a}-37^{\circ} \mathrm{C} ; \mathrm{b}-46{ }^{\circ} \mathrm{C} ; \mathrm{c}-60{ }^{\circ} \mathrm{C}$

This is due to the debris is constantly pushed to the boundary and involved in the wear process during the balldisc friction process from point contact to surface contact, which results in the main wear mechanism of the boundary area being abrasive wear. However, the number of plough furrows in the central region and the boundary region is not much different at $46{ }^{\circ} \mathrm{C}$ and $60{ }^{\circ} \mathrm{C}$, which further proves that the protein precipitation as a third body participates in the whole wear process.

The micro-morphology of the wear center of UHMWPE at different lubricant temperature is observed in Fig. 7. At $20^{\circ} \mathrm{C}$ (as shown in Fig. 7 a), there are obvious crack morphologies in the wear center and debris can be found locally. At the same time, there is no obvious plough morphology in the wear center, which shows that the wear mechanism of the wear center is mainly the contact fatigue wear. With the increase of lubricant temperature, the area of plastic deformation zone caused by adhesion wear in wear morphology of UHMWPE increases gradually. Fig. $7 \mathrm{~b}$ shows that the degree of plastic deformation in the wear center is the most serious at $60{ }^{\circ} \mathrm{C}$. This is mainly due to the fact that when the lubricant temperature is $60{ }^{\circ} \mathrm{C}$, the frictional heat will accumulate continuously with the friction process, resulting in the continuous increase of the temperature of wear surface. As a result, the hot deformation temperature of UHMWPE (only about $79-88^{\circ} \mathrm{C}$ ) can be easily reached in the wear center. Under the synergistic effect of friction, a large number of plastic deformations can be produced on the wear surface. This conclusion is similar to Galetz's research [27]. In his research, the deformation mechanism of UHMWPE will change obviously at $50{ }^{\circ} \mathrm{C}$, and the deformation will accelerate under the combined action of tribological loading at elevated temperature. In addition, the wear surface is accompanied by typical exfoliation and plough groove morphology under the combined action of matrix abrasive particles and protein precipitation, which shows that the wear mechanism of the wear central at this condition is mainly adhesion wear and abrasive wear. In addition, in vitro simulation experiments by Liao et al. [20, 21], the change of lubricant temperature can't influence the morphology of debris. But at lower lubricant temperature, the proportion of fibrous particles debris is higher. According to our research, the change of lubricant temperature is closely related to the wear mechanism of the matrix, especially for UHMWPE materials. 


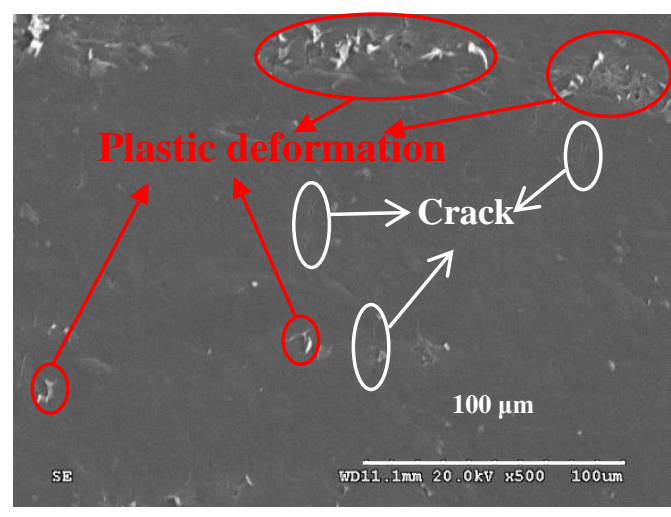

a

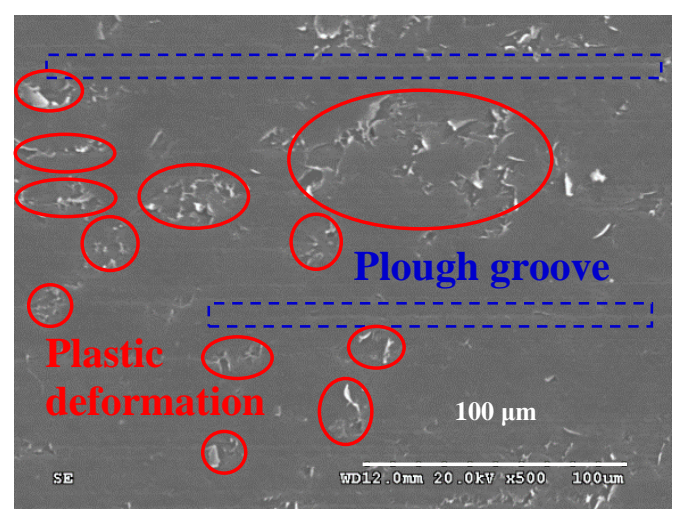

$\mathrm{b}$

Fig. 7. Micro-morphology of the wear center of UHMWPE at different lubricant temperature: $\mathrm{a}-20{ }^{\circ} \mathrm{C} ; \mathrm{b}-60{ }^{\circ} \mathrm{C}$

Because of the low thermal deformation temperature and low thermal conductivity of UHMWPE, the interface temperature of the wear zone can easily reach the thermal deformation temperature of UHMWPE under the combined action of the accumulation of frictional heat and the high lubricant temperature. The wear mechanism changes significantly at this time. At the same time, the soften surface can reduce the abrasion force, resulting in a fall off tendency of friction coefficients, which is also consistent with Ge's findings [26].

\section{CONCLUSIONS}

As a neglected factor, the lubricant temperature has a significant effect on the wettability and lubrication characteristics of lubricant. There is a certain correlation between the contact angle and lubrication performance of lubricant, which becomes very complex when the temperature is high enough to change the characteristics of lubricant. The influence of lubricant temperature on the wear resistance and wear mechanism of UHMWPE and Ti6Al7Nb is obvious. It is mainly manifested in that the precipitation of protein and the amount of protein involved in interfacial friction are different under different loading condition and different lubricant temperature. The number of plough furrows in the central region and the boundary region of Ti6Al7 $\mathrm{Nb}$ wear morphology is not significantly different at $46{ }^{\circ} \mathrm{C}$ and $60{ }^{\circ} \mathrm{C}$, which further proves that the protein precipitation as a third body participates in the whole wear process. At the same time, the mechanism of protein precipitation as a protective layer or a third body abrasive particle affecting the friction process is complex, which needs further experimental study. In addition, for the prosthesis substitutes with low thermal deformation temperature, such as UHMWPE, the instantaneous high temperature caused by the accumulation of frictional heat can easily change their wear resistance mechanism fundamentally. The generation of plastic deformation can also aggravate wear. At the same time, the gradual increase of protein precipitation during friction process with the increase of lubricant temperature is not only a unilateral effect of temperature, but also a result of the synergistic effect of frictional heat accumulation and frictional shear force.

\section{Acknowledgments}

This paper was supported by National Natural Science Foundation of China (No. 51705223) and University Natural Science Research Project of Jiangsu Province (No. 17KJB460005).

\section{REFERENCES}

1. Langhorn, J., Borjali, A., Hippensteel, E., Nelson, W., Raeymaekers, B. Microtextured CoCrMo Alloy for Use in Metal-on-polyethylene Prosthetic Joint Bearings: Multidirectional Wear and Corrosion Measurements Tribology International 124 2018: pp. 178-183. https://doi.org/10.1016/j.triboint.2018.04.007

2. Borges, R.A., Choudhury, D., Zou, M. 3D Printed PCU/UHMWPE Polymeric Blend for Artificial Knee Meniscus Tribology International 122 2018: pp. 1-7. https://doi.org/10.1016/j.triboint.2018.01.065

3. Gispert, M.P., Serro, A.P., Colaço, R., Saramago, B. Friction and Wear Mechanisms in Hip Prosthesis: Comparison of Joint Materials Behaviour in Several Lubricants Wear 260 (1) 2006: pp. 149-158. https://doi.org/10.1016/j.wear.2004.12.040

4. Askari, E., Flores, P., Dabirrahmani, D., Appleyard, R. A Review of Squeaking in Ceramic Total Hip Prostheses Tribology International 93 2016: pp. 239-256. https://doi.org/10.1016/j.triboint.2015.09.019

5. Sagbas, B., Durakbasa, M.N. Effect of Surface Patterning on Frictional Heating of Vitamin E Blended UHMWPE Wear 303 (1-2) 2013: pp. 313-320. https://doi.org/10.1016/j.wear.2013.03.023

6. Sagbas, B., Durakbasa, M.N., Sagbas, M., Koyun, A. Measurement and Theoretical Determination of Frictional Temperature Rise Between Sliding Surfaces of Artificial Hip Joints Measurement 51 (1) 2014: pp. 411-419. https://doi.org/10.1016/j.measurement.2013.12.020

7. Fialho, J.C., Fernandes, P.R., Eça, L., Folgado, J. Computational Hip Joint Simulator for Wear and Heat Generation Journal of Biomechanics $40(11)$ 2007: pp. $2358-2366$. https://doi.org/10.1016/j.jbiomech.2006.12.005

8. Hu, C.C., Liau, J.J., Lung, C.Y., Huang, C.H., Cheng, C.K. A Two-dimensional Finite Element Model for Frictional Heating Analysis of Total Hip Prosthesis Materials Science \& Engineering C-Materials for Biological Applications 17 (1) 2001: pp. 11-18. https://doi.org/10.1016/s0928-4931(01)00328-9 
9. Bergmann, G., $\quad$ Graichen, F., Rohlmann, A., Verdonschot, N., Lenthe, G.H. Frictional Heating of Total Hip Implants Part 1: Measurements in Patients Journal of Biomechanics 34 (4) 2001: pp. 421-428. https://doi.org/10.1016/S0021-9290(00)00188-3

10. Pritchett, J.W. Heat Generated by Hip Resurfacing Prostheses: An in Vivo Pilot Study Journal of long-term effects of medical implants 21 (1) 2011: pp. 55-62. https://doi.org/10.1615/JLongTermEffMedImplants.v21.i1.40

11. Davidson, J.A., Gir, S., Paul, J.P. Heat Transfer Analysis of Frictional Heat Dissipation during Articulation of Femoral Implants Journal of Biomedical Materials Research 22 (S14) 1988: pp. 281-309. https://doi.org/10.1002/jbm.820221408

12. Bergmann, G., Graichen, F., Rohlmann, A., Verdonschot, N., Lenthe, G.H. Frictional Heating of Total Hip Implants Part 2: Finite Element Study Journal of Biomechanics 34 (4) 2001: pp. 429-435. https://doi.org/10.1016/S0021-9290(00)00234-7

13. Shahemi, N., Liza, S., Abbas, A.A., Merican, A.M. Longterm Wear Failure Analysis of Uhmwpe Acetabular Cup in Total Hip Replacement Journal of the Mechanical Behavior of Biomedical Materials 87 2018: pp. 1-9. https://doi.org/10.1016/j.jmbbm.2018.07.017

14. Choudhury, D., Ranuša, M., Fleming, R.A., Vrbka, M., Křupka, I., Teeter, M.G., Goss, J., Zou, M. Mechanical Wear and Oxidative Degradation Analysis of Retrieved Ultra High Molecular Weight Polyethylene Acetabular Cups Journal of the Mechanical Behavior of Biomedical Materials 79 2018: pp. 314-323.

https://doi.org/10.1016/j.jmbbm.2018.01.003

15. Park, J.W., Park, K.B., Suh, J.Y. Effects of Calcium Ion Incorporation on Bone Healing of Ti6Al4V Alloy Implants in Rabbit Tibiae Biomaterials $28(22)$ 2007: pp. 3306-3313. https://doi.org/10.1016/j.biomaterials.2007.04.007

16. Cai Z.B., Zhang, G.A., Zhu, Y.K., Shen, M.X., Wang, L.P., Zhu, M.H. Torsional Fretting Wear of a Biomedical Ti6A17Nb Alloy for Nitrogen Ion Implantation in Bovine Serum Tribology International 59 2013: pp. $312-320$. https://doi.org/10.1016/j.triboint.2012.06.009

17. Basiaga, M., Kajzer, W., Walke, W., Kajzer, A., Kaczmarek, M. Evaluation of Physicochemical Properties of Surface Modified Ti6Al4V and Ti6Al7Nb Alloys Used for Orthopedic Implants Materials Science \& Engineering C-Materials for Biological Applications 68 2016: pp. $851-860$. https://doi.org/10.1016/j.msec.2016.07.042

18. Li, Z.Y., Cai, Z.B., Wu, Y.P., Zhu, M.H. Effect of Nitrogen Ion Implantation Dose on Torsional Fretting Wear Behavior of Titanium and Its Alloy Transactions of Nonferrous Meatals Society of China 27 (2) 2017: pp. 324-335. https://doi.org/10.1016/S1003-6326(17)60037-2

19. Lu, Z., Mckellop, H. Frictional Heating of Bearing Materials Tested in a Hip Joint Wear Simulator Proceedings of the Institution of Mechanical Engineerings Part H-Journal of Engineering in Medicine $211(1)$ 1997: pp. $101-108$. https://doi.org/10.1243/0954411971534728

20. Liao, Y.S., Mckellop, H., Lu, Z., Campbell, P., Benya, P. The Effect of Frictional Heating and Forced Cooling on the Serum Lubricant and Wear of UHMW Polyethylene Cups Against Cobalt-chromium and Zirconia Balls Biomaterials 24 (18) 2003: pp. 3047-3059. https://doi.org/10.1016/s0142-9612(03)00148-0

21. Liao, Y.S., Benya, P., McKellop, H. Effect of Protein Lubrication on The Wear Properties of Materials for Prosthetic Joints Journal of Biomedical Materials Research 48 (4) 1999: pp. $465-473$.

https://doi.org/10.1002/(sici)1097-4636(1999)48:4<465::aidjbm10>3.0.co;2-y

22. Young, T. An Essay on the Cohesion of Fluids Philosophical Transactions of the Royal Society of London 95 1805: pp. $65-87$. https://doi.org/10.1098/rstl.1805.0005

23. Kwok, S.C.H, Wang, J., Chu, P.K. Surface Energy, Wettability, and Blood Compatibility Phosphorus Doped Diamond-like Carbon Films Diamond and Related Materials 14 (1) 2005: pp. 78-85. https://doi.org/10.1016/j.diamond.2004.07.019

24. Gispert, M.P., Serro, A.P., Colaço, R., Saramago, B. Friction and Wear Mechanisms in Hip Prosthesis: Comparison of Joint Materials Behaviour in Several Lubricants Wear 260 (1) 2006: pp. 149-158. https://doi.org/10.1016/j.wear.2004.12.040

25. Kubiak, K.J., Wilson, M.C.T., Mathia, T.G., Carval, P.H. Wettability Versus Roughness of Engineering Surfaces Wear 271 (3) 2011: pp. 523-528. https://doi.org/10.1016/j.wear.2010.03.029

26. Ge, S.R., Wang, Q.L., Zhang, D.K., Zhu, H., Xiong, D.S., Huang, C.H., Huang, X.L. Friction and Wear Behavior of Nitrogen Ion Implanted UHMWPE Against $\mathrm{ZrO} 2$ Ceramic Wear 255 (7) 2003: pp. 1069-1075. https://doi.org/10.1016/S0043-1648(03)00269-2

27. Galetz, M.C., Glatzel, U. An Activated Energy Approach for Accelerated Testing of the Deformation of UHMWPE in Artificial Joints Journal of the Mechanical Behavior of Biomedical Materials 3 (4) 2010: pp. 331-8. https://doi.org/10.1016/j.jmbbm.2010.01.004

(c) Wang et al. 2021 Open Access This article is distributed under the terms of the Creative Commons Attribution 4.0 International License (http://creativecommons.org/licenses/by/4.0/), which permits unrestricted use, distribution, and reproduction in any medium, provided you give appropriate credit to the original author(s) and the source, provide a link to the Creative Commons license, and indicate if changes were made. 